Volume 7, Issue 1, 133 - 150.

ISSN: $2165-8714$

http://www.eu-jer.com/

\title{
A Path Analysis Model Pertinent to Undergraduates' Academic Success: Examining Academic Confidence, Psychological Capital and Academic Coping Factors *
}

\author{
Berke Kirikkanat ** \\ Yeditepe University, TURKEY
}

\author{
Makbule Kali Soyer \\ Marmara University, TURKEY
}

Received: November 5, 2017 - Revised: December 15, $2017 \cdot$ Accepted: December 21, 2017

\begin{abstract}
The major purpose of this study was to create a path analysis model of academic success in a group of university students, which included the variables of academic confidence and psychological capital with a mediator variable - academic coping. 400 undergraduates from Marmara University and Istanbul Commerce University who were in sophomore, junior and senior years participated in the study. The Academic Behavioral Confidence Scale, the Academic Coping Strategies Scale and the Psychological Capital Test Battery composed of the Academic Self-Efficacy Scale, the Life Orientation Test, the Hope Scale and the Resilience Scale were utilized to disclose the predictive roles of these variables on academic success. The results of path analyses showed that academic confidence and psychological capital had pivotal direct and indirect effects on academic success via the mediator variable academic coping. Academic coping had also a direct influence on academic success. The findings of the study are essential for telling both vocational counselors and educational psychologists the fact that career interventions for university students should consider the non-cognitive factors on their academic achievements.
\end{abstract}

Keywords: Academic success, academic confidence, psychological capital, academic coping strategies, university students.

To cite this article: Kirikkanat, B., \& Kali Soyer, M. (2018). A path analysis model pertinent to undergraduates' academic success: Examining academic confidence, psychological capital and academic coping factors. European Journal of Educational Research, 7(1), 133-150. doi: 10.12973/eu-jer.7.1.133

\section{Introduction}

Education includes all the activities aimed at making a change in one's deeds (Demirel, 2015). In other words, it refers to a process in which an individual experiences behavioral changes while learning the social values of his society. During this process, he is evaluated according to his behaviors, thoughts and feelings shaped by his learning experiences. Based on the assessments like grades, scores on standardized tests etc., his degree of performance pertinent to the development of his abilities, interests and motives in an educational environment represents his degree of success (Steinberg, 2002).

The previous studies (Brown, Lent, \& Larkin, 1989; Schaefers, Epperson, \& Nauta, 1997; Thomas, \& Rohwer, 1986) examining undergraduates' academic success show that exam grades, GPA scores and degree of completion are considered as the criteria for one's academic accomplishments. To Bandura (1997), the best indicator of a university student's success is his GPA score. This score summarizes all efforts he made through his educational process (York, 2015). However, the economic, technological and scientific improvements since the $20^{\text {th }} \mathrm{cc}$. lead to the emergence of students' non-cognitive qualities as the significant determinants of their academic successes (Adebayo, 2008; Gunduz, 2014; Kuzgun, 2013; Ting, 2003).

Several researchers (DeBerard, Spielsmans, \& Julka, 2004; Ensign \& Woods, 2014; Huang, 2011; Messick, 1979; Randsdell, 2001; Richardson, Abraham, \& Bond, 2012; Fenollar, Roman, \& Cuestas, 2007) try to uncover the multidimensionality of academic success by investigating different non-cognitive variables such as past educational life, coping strategies, social/family support, quality of one's life, one's efforts to be successful, degree of dedication to

\footnotetext{
* The present study was conducted as the PhD thesis in the Program of Guidance and Counseling, Institute of Educational Sciences, Marmara University, named 'A Path Analysis Model Pertinent to Undergraduates' Academic Success: Examining Academic Confidence, Psychological Capital and Academic Coping Factors' by B. Kirikkanat whose PhD advisor is M. K. Soyer, Assist. Prof. It was orally presented at the 6th International Congress on Current Debates in Social Sciences.
}

** Corresponding author:

Berke Kirikkanat, Yeditepe University, Guidance and Counseling, Istanbul - Turkey.

Email: berke.kirikkanat@yeditepe.edu.tr 
educational process, participation to courses, academic self-efficacy, achievement motivation, degree of responsibility, ability of time management, ability to identify proper vocational goals and effective learning strategies, study quality and length, self-concept, creativity, socio-economic status and so on. As university students need powerful psychological resources promoting their academic success and enabling them to survive in a competitive business world (Luthans, Luthans, \& Jensen, 2012), psychological capital, academic confidence and academic coping strategies become critical components of their educational process (Hsieh, Sullivan, Sass, \& Guerra, 2012; Luthans et al., 2012; Nicholson, Putwain, Connors, \& Hornby-Atkinson, 2013; Sander \& Sanders, 2006; Siu, Bakker, \& Jiang, 2014).

Psychological capital refers to one's psychological stamina composed of four components - hope, efficacy, resilience and optimism - determining one's positive psychological state (Luthans, Youssef, \& Avolio, 2007). Each component contributes to one's self-concept, and shapes one's ideals in his life. Hope involves one's capacity to find the pathways of attaining the individual goals and to utilize these pathways effectively (Snyder, 2002). To Snyder, students having high levels of hope are more successful in academic fields than the other ones due to the fact that: 1) Students who have high degrees of hope try to create lots of alternative solutions to reach their academic goals, 2) They are internally motivated to pursue these ways of solutions. They are keen to find each clue pertinent to their goals in educational environment.

The second component of psychological capital is self-efficacy, defined as one's beliefs about his skills in a specific field in social cognitive theory (Bandura, 1982). When this concept is applied to academic environments, it turns into academic self-efficacy, one's beliefs about his skills necessary for required academic performance in his field (Bandura, 1977; Schunk, 1991). Previous studies (Brown et al., 1989; Multon, Brown, \& Lent, 1991; Gore; 2006; Putwain, Sander, \& Larkin, 2013) show that students having high degrees of academic self-efficacy display high grades in their courses and get high scores from the standardized tests. To Chemers, Hu and Garcia (2001), the main reason behind this outcome is that these students think they have the enough strength to overcome all academic tasks and responsibilities in their areas.

The third component of psychological capital is resilience. Resilience refers to one's positive adaptation to difficult conditions in which he is involved, and resistance to every kind of stress in his life (Masten \& Reed, 2002). Resilience has a great importance in one's academic life. Especially, students having high degrees of resilience attempt to maintain their academic status in an optimal level despite challenging problems in their educational areas, and they consider these struggles as the opportunities to enhance themselves (Martin \& Marsh, 2009).

The last component of psychological capital, optimism, on the other hand, is related to one's anticipations about the future. Positive expectations toward life makes an individual persist in solving the obstacles effectively. This tendency derives from the fact that the individual believes the troubles in life can be surmounted as its reasons are changeable entities (Carver \& Scheier, 2002). When this concept is reflected in academic world, optimist students rely on the idea that academic failures can be reduced as they are alterable situations (Singh \& Jha, 2013).

Another important factor on students' academic success is academic confidence. Academic confidence can be defined as students' cognitive comprehensions about whether they can fulfill educational requirements of a university education effectively (Nicholson et al., 2013). In other words, academic confidence refers to students' beliefs about their study behaviors necessary for their major fields (Sanders \& Sander, 2003). It is different from academic self-efficacy as it indicates a general belief about whether one is able to accomplish all academic chores at a university or not (Nicholson et al., 2013).

The other factor determining students' academic achievements is coping strategies. To Skinner, Edge, Altman, and Sherwood (2003), coping strategies include one's reactions to stress. Intense academic overload of university life like homework, projects, exams etc., changing social environment and friendships, new tasks and responsibilities etc. result in high degrees of academic stress in students (Abouserie, 1994; Carveth, \& Geese, 1996; Ross, Niebling, \& Heckert, 1999). In such a nerve-racking atmosphere, university students try to use coping strategies specific to the academic life (Struthers, Perry, \& Menec, 2000). These strategies are called as academic coping strategies (Hsieh et al., 2012; Sullivan, 2010; Thien, \& Razak, 2013). They are categorized into three groups: Approach, avoidance and social support coping strategies (Sullivan, 2010). In approach coping strategy, students manifest active attempts to modify the problematic situation. They are motivated to deal with the academic challenges efficiently. In avoidance coping strategy, students stay away from stressful states by ignoring their academic problems. In social support, students demand others' emotional and cognitive help in order to deal with their problems comprehensively.

To Sander and Sanders (2006), students' self-beliefs about showing necessary study behaviors in their academic careers (academic confidence) have a predictive role on their coping strategies and academic performance. For Luthans et al. (2012), high degrees of psychological capital can facilitate students' academic success. Specifically, each component in psychological capital (hope, self-efficacy, resilience, optimism) shapes students' academic coping strategies (Fontaine, Manstead, \& Wagner, 2004; Gonzales-Torres \& Artuch-Garde, 2014; Hatchett \& Park, 2004; Khan, 2013; Nes \& Segerstrom, 2006; Onwuegbuzie \& Snyder, 2000; Steinhardt \& Dolbier, 2008) and their accomplishments (Chemers et al., 2001; Day, Hanson, Maltby, Proctor, \& Wood, 2010; Gore, 2006; Kwok, Hughes, \& Luo, 2007; Ruthig, Perry, Hall, \& Hladkyj, 2004; Snyder, Shorey, Cheavens, Pulvers, Adams III, \& Wiklund, 2002) Besides, students' 
academic coping strategies have modifying roles on their academic performance (Hsieh et. al., 2012; Kuncharin \& Mohamad, 2014).

In Turkey whose cultural patterns give priority to the collectivistic concerns like interdependence, devotion to family values, social profits and so on (Kagitcibasi, 2005), educational system can be depicted as paternal, rigid, restraining, and overprotective (Fisek, 1982). Students are required to gain lots of knowledge necessary for obtaining high scores in college entrance examinations. Students in high school education have to have these examinations to reach an upper educational degree (Esen, 2010). According to Ozguven (2014), the criteria of students' academic success in Turkey can be summarized as reaching the general goals and desired behaviors for the educational degree they are involved, having high performance according to general success degree of the class, knowing the majority of the learning material and being competent in their study skills and abilities.

Based on the statistics reported in 2016-2017 in Turkey, higher education system includes 112 public and 67 private universities and also 5 vocational training schools (The Council of Higher Education, 2017a). The total number of university students in 2016-2017 academic year is 6.627.505 (The Council of Higher Education, 2017b). Besides, the number of graduate students in the same year is 753.480 (The Council of Higher Education, 2017c). Relying on the unemployment statistics reported by Turkish Statistical Institute (2017), the rate of unemployment is $10.6 \%$. Besides, the number of master and doctorate programs is 12188 and 5235 respectively (The Council of Higher Education, 2017d). Thus, academic success in higher education in Turkey is critical in the sense that one's achievement level makes him unique by determining if he can pursue a graduate study in his life or if he can be a preeminent employer in business world. Despite many studies examining the impacts of psychological variables on academic success, there is no research investigating the relations among psychological capital, academic confidence and academic coping strategies in literature. Examining their predictive powers is very essential to improve undergraduates' academic career sufficiently. Therefore, the present study tries to answer that question - "To what extent do psychological capital, academic confidence and academic coping factors explain university students' academic success?" Based on that question, the study aims to form a path analysis model (see Figure 1) in which these psychological variables have predictive roles on academic success.

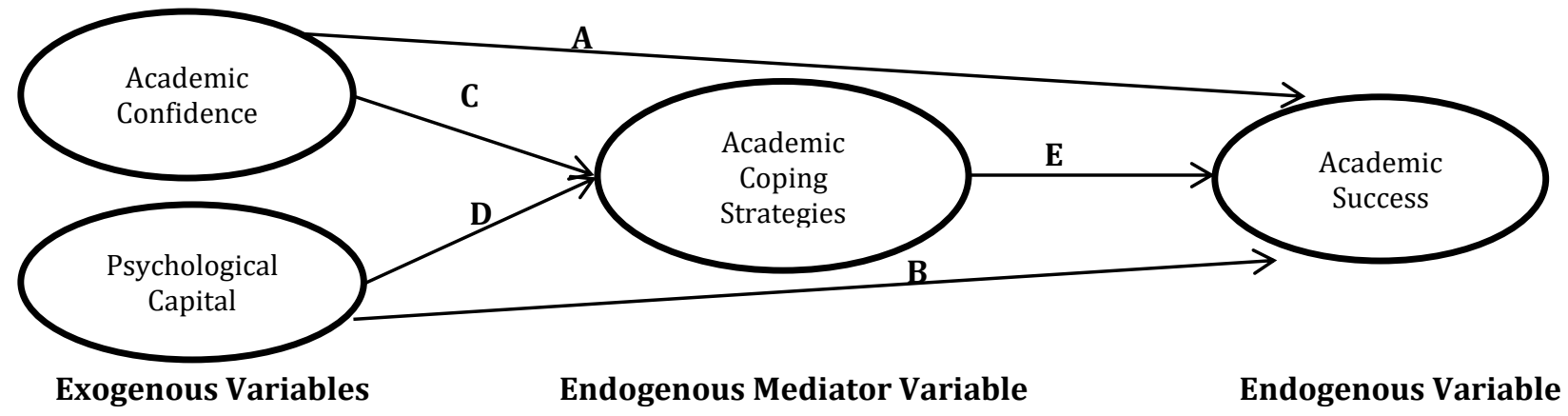

Figure 1. Proposed model of academic success. $A=$ the hypothesized relationship between academic confidence and academic success. $B=$ the hypothesized relationship between psychological capital and academic success. $C=$ the hypothesized relationship between academic confidence and academic coping strategies. D=the hypothesized relationship between psychological capital and academic coping strategies. E= the hypothesized relationship between academic coping strategies and academic success.

In the proposed model, academic confidence and psychological capital are exogenous/independent variables. Academic coping strategies and academic success are endogenous/dependent variables. In the model, academic coping strategies are the endogenous/dependent mediator variable between academic confidence, psychological capital and academic success.

Based on the information in the literature, academic confidence and psychological capital are assumed to be the resources of academic coping strategies. To Curlette, Matheny, Aycock, Pugh, Taylor and Canella (1993), there are five resources of academic coping strategies including social confidence (the degree of getting along with one's friends), behavioral control (the degree of one's collaboration with others), peer acceptance (the degree of others' acceptance), academic confidence (the degree of believing one's study behaviors in his academic field) and family support (the degree of attaining family assistance and acceptance). For these scholars, academic confidence helps the one cope with academic stress more effectively as he believes his study behaviors will contribute to his success. In addition, if a person believes that he can control and solve an academic problem on his own, he will be more likely to use approach coping strategy in his life. In this respect, if he has high levels of academic confidence, he will try to find out possible ways of dealing with that problem (Suls \& Fletcher, 1985). 
For Lazarus and Folkman (1984), one's coping resources encompass his existential beliefs, hope, beliefs about controlling his conditions, problem solving and social skills, and social support. Besides, one's degree of optimisim, selfesteem, self-efficacy, and self-control are also the significant coping resources (Taylor \& Stanton, 2007). Thus, psychological capital including hope, optimism, self-efficacy and resilience can be an important ingredient of academic coping strategies. To these scholars, having high levels of these psychological variables allows the one to handle with the challenging academic situations better. In this way, he can consider the positive sides of their difficult experiences, leading him to believe that he can change these rough circumstances in a desirable way (Luthans et al., 2007). Therefore, one's academic coping strategies are pivotal factors of obtaining good academic performance as they let undergraduates experience emotional and academic stress less often (Steptoe \& Marnot, 2003; Sullivan, 2010).

Relying on this information, the hypotheses related to the direct, indirect and total effects of academic confidence, psychological capital and academic coping strategies on academic success are suggested below:

\section{a) Hypotheses about the direct effects in the model:}

Path A (Academic Confidence $\rightarrow$ Academic Success): Students having high levels of academic confidence will have high GPA scores.

Path B (Psychological Capital $\rightarrow$ Academic Success): Students having high levels of psychological capital will have high GPA scores.

Path A \& Path B (Academic Confidence \& Psychological Capital $\rightarrow$ Academic Success): Students having high levels of academic confidence and psychological capital will have high GPA scores.

\section{b) Hypotheses about indirect effects in the model:}

Path C \& D \& E (Academic Confidence \& Psychological Capital $\rightarrow$ Academic Coping $\rightarrow$ Academic Success): Students having high levels of academic confidence and psychological capital scores will have high levels of scores of approach and social support academic coping strategies; leading to high GPA scores. On the other hand, students having low levels of academic confidence and psychological capital will have high levels of scores of avoidance academic coping strategy; resulting in low GPA scores.

\section{c) Hypotheses about total effects in the model:}

Path $A \& B$ and Path $C \& D \& E$ (Academic Confidence and Psychological Capital $\rightarrow$ Academic Success) and (Academic Confidence and Psychological Capital $\rightarrow$ Academic Coping $\rightarrow$ Academic Success)\}: Students having high levels of academic confidence and psychological capital will not have high GPA scores. Students having high levels of academic confidence and psychological capital scores will have high levels of scores of approach and social support academic coping strategies; leading to high GPA scores. On the other hand, students having low levels of academic confidence and psychological capital will have high levels of scores of avoidance academic coping strategy; resulting in low GPA scores.

\section{Methodology}

\section{Research Design}

The present study was based on multifactorial predictor correlational research design. This design contains the efforts to figure out the variations on dependent variables made by independent variables. Its objective is to analyze the direct and indirect causal relations among the variables (Fraenkel \& Wallen, 2006). In this respect, the present study aimed to analyze the direct and indirect links among the variables of academic confidence, psychological capital, academic coping and academic success.

\section{Research Sample}

The population of the study included undergraduate students who were in sophomore, junior and senior years in the faculties of social and life sciences in Istanbul Commerce University and Marmara University in the academic year of 2015-2016 in Turkey.

The sample was developed via proportional stratified sampling method. Stratified sampling method includes a process in which homogenous groups of the population are identified based on similar characteristics (Cohen, Manion, \& Morrison, 2007). In proportional stratified sampling method, the portion of the strata in the sample is decided based on the rate of each strata in the population (Rao, 2000).

In the sampling method, firstly, the departments in the faculties of social and life sciences in Istanbul Commerce University were listed. Then, based on this list, the departments in the same faculties of Marmara University were selected. These departments were Counseling, Psychology, Sociology, Economics, Computer Engineering, Industry Engineering, Mathematics and Math Teaching. 
The population regarding these departments in Istanbul Commerce University (ICU) and Marmara University (MU) was composed of 2894 undergraduates $\left(N_{I C U}=748 ; N_{M U}=2146\right)$. In order to identify the sample size of the population, the Cochran's formula was used (Barlett, Kotrlik, \& Higgins, 2001) and accounted as 340.

Due to the possibility of the missing and outlier data, 421 undergraduates participated in the study. However, 18 participants constituted the missing data as they did not answer the questions in the scales completely. Because this data made up less than $5 \%$ of the total data, listwise deletion method was utilized (Kline, 2005; Tabachnick \& Fidell, 2007). The rest of the data (403 participants) was analyzed whether there were outliers according to Mahalonobis distance calculation. In this regard, 3 participants were identified as outliers and excluded from the data because they fulfilled all the items in an expected desirable manner $(p<.001)$ Therefore, the analyses of the study were carried out with 400 participants $\left(n_{M U}=296 ; n_{I C U}=104\right)$.

176 undergraduates (44\%) from the faculty of social sciences and 120 undergraduates (30\%) from the faculty of life sciences in MU, 32 undergraduates (8\%) from the faculty of social sciences and 72 undergraduates (18\%) from the faculty of life sciences in ICU participated in the study.

The sample was composed of 277 female (69.3\%) and 123 male (30.8\%) undergraduates. The age ranged from 18 to 26 , and the average age was $21(S D=1.42)$. There were 130 sophomore $(32.5 \%), 136$ junior (34\%) and 134 senior $(33.5 \%)$ students in the sample. GPA score of the students varied from 1.20 to 3.92, and the average GPA score was 2.80 $(S D=.55)$.

\section{Data Collection Instruments}

- Personal Information Form: Personal Information Form was developed by the researchers in order to obtain the data about descriptive characteristics of the sample. The form included questions regarding age, gender, department, class level and GPA score.

- $\quad$ The Academic Behavioral Confidence Scale (the ABC Scale): The ABC Scale is a scale developed by Sanders and Sander (2003) in order to determine the extent of academic confidence in university students. Its Turkish version (Kirikkanat \& Soyer, 2015) was used in the study. The adapted version was composed of 16-items with three factors-Academic Study Planning, Verbalizing, and Assignment/Project Organization on a 5-point scale. The criterion validity of the scale was examined through the Turkish version of the Revised Two-Factor Study Process Questionnaire made by Yilmaz and Orhan (2011). The results showed that there were statistically significant positive correlations between Academic Study Planning, Verbalizing, and Assignment/Project Organization subscales and deep approach to learning ( $r=.41, r=.34$, and $r=.35, p<.001$ respectively) unlike their correlations with surface approach to learning $(r=-.24, r=-.22$, and $r=-.28, p<.001$ respectively). Cronbach alpha coefficient of the scale was .88. Besides, Cronbach alpha coefficients of Academic Study Planning, Verbalizing, and Assignment/Project Organization were .81, .76 and .81 respectively. Test-retest reliability coefficients of each subscale were $.93, .61$, and .75 respectively $(p<.001)$.

- The Psychological Capital Test Battery: The Psychological Capital Test Battery was composed of 55 items which were made of four scales:

a) The Academic Self-Efficacy Scale (the ASE Scale): The ASE Scale is a scale developed by Jerusalem and Scharzer (1981), whose aim is to estimate the degrees of academic self-efficacy in university students (cited in Yilmaz, Gurcay, \& Ekici, 2007). The scale reveals the level of one's self-assurance about his skills necessary for meeting an academic requirement successfully. Its Turkish version was formed by Yilmaz et al. (2007). This version encompassed 7-items with one factor on a 4-point scale. Cronbach alpha coefficient of the scale was .79.

b) The Life Orientation Test (the LOT): The LOT is a scale flourished by Scheier and Carver (1985) in order to determine the extent of one's optimism. Its adapted version was made by Aydin and Tezer (1991). The version included 12 items on a 5-point scale. The criterion validity of the test was examined through Beck Depression Scale. The results manifested that there was a significantly negative correlation between two scales $(r=-.56, p<.001)$. Cronbach alpha coefficient value of the test was .72. The test-retest reliability coefficient of the test was .77 $(p<.001)$

c) The Hope Scale: The Hope Scale is a measurement tool developed by Snyder, Harris, Anderson, Holleran, Irving, Sigmon et al. (1991) so as to examine the degree of one's hope in his life. Its Turkish version was formed by Akman and Korkut (1993). It involved 12 items on a 4-point scale. Its criterion validity was pondered via Beck Depression Scale and the Life Orientation Test. The findings showed that there was a significantly negative relation between hope and depression $(r=-.32, p<.005)$ unlike its correlation with 
optimism $(r=.50, p<.001)$. Cronbach alpha coefficient of the scale was .65. Test-retest reliability value was $.66(p<.001)$.

d) The Resilience Scale: The Resilience Scale is an assessment tool formed by Wagnild and Young (1993) in order to measure the degree of one's resilience against difficult situations in his life. The scale was adapted by Terzi (2006) into Turkish language. It contained 24-items on a 7-point scale. Its criterion validity was tested through Generalized Self-Efficacy Scale. The results displayed that there was a positive correlation between two scales $(r=.83, p<.01)$. Cronbach alpha coefficient of the scale was .82 . Test-retest reliability coefficient value was .84 $(p<.05)$.

- $\quad$ The Academic Coping Strategies Scale (the ACS Scale): The ACS Scale is a scale formed by Sullivan (2010) so as to identify the coping strategies utilized by university students in academic settings. Its adapted version (Kirikkanat \& Soyer, 2016) was used in the present study. This version consisted of 33-items with a three factor structure - Approach, Avoidance and Social Support on a 5-point scale (1=never; $5=$ almost always). The scale had a starting question called "Think about a time when you received a low grade on an important exam, significantly lower than what you usually get." The items were evaluated based on this prompt question.

The criterion validity of the scale was pondered via the Academic Self-Efficacy Scale adapted by Yilmaz et al. (2007), and the Achievement Goal Orientations Scale adapted by Akin and Cetin (2007). The results indicated that there were significantly positive correlations between Approach subscale and academic self-efficacy $(r=-$ $.33, p<.001)$, and Learning $(r=.42, p<.001)$, Performance-Approach $(r=.14, p<.001)$ subscales unlike Performance-Avoidance subscale $(r=-.10, p<.05)$. Avoidance subscale had significantly positive correlations with Performance-Avoidance subscale $(r=.26, p<.001)$ while it had negative correlation with Learning subscale $(r=-.24, p<.001)$, and academic self-efficacy $(r=-.21, p<.001)$. Social Support subscale had significantly positive relations with Learning $(r=.21, p<.001)$, Performance-Approach $(r=.17, p<.001)$ and Performance-Avoidance $(r=.12, p<.001)$ when in fact it had no statistically essential link with academic self-efficacy $(r=-.04, p>.05)$.

Cronbach alpha coefficients of Approach, Avoidance and Social Support were $.89, .78$ and .82 respectively. Testretest reliability values of Approach, Avoidance and Social Support subscales were .73, .71 and .63 respectively $(p<.001)$.

\section{Analyzing of Data}

In order to examine the predictive roles of academic confidence, psychological capital and academic coping strategies on academic success of university students, the path analyses, one of the structural equation modelling (SEM), were conducted through LISREL 8.80.

SEM refers to a statistical method of testing structural relations among various variables in a comprehensive manner (Hoyle, 1995). It involves two kinds of models: the measurement and structural models. The former summarizes the relations between latent variables (i.e. the theoretical factors) and observed variables/indicators (i.e. directly testable variables) while the later condenses the relations among latent variables (Hoyle, 1995).

Path analysis reflects a kind of analysis investigating direct and indirect hypothetical causal relations among the variables (Schumacker \& Lomax, 2010). In this analysis, the interactions among variables are in the ways of the direct, indirect and total effects. (Raykov \& Marcoulides, 2006). Path diagrams were figured out based on theoretical information about the variables.

In order to test the mediator role of academic coping strategies, the conditions suggested by Baron \& Kenny (1986) were analyzed. According to these researchers, there are three conditions which should be fulfilled if a variable is considered as a mediator: 1) The direct paths in which independent variables lead to significant variations in dependent variables must be statistically significant. 2) The indirect paths in which independent variables have an unstraightforward impact on dependent variables must be statistically significant. 3) The total effects in which the direct and indirect paths are included must be analyzed; and if the direct paths in that model are revealed as statistically insignificant, the variable should be considered as full mediator. But, if the significant level in the direct paths decreases, the variable must be regarded as partial mediator.

In the study, two-step modelling approach was pursued (Anderson \& Gerbing, 1988). Firstly, the measurement model was evaluated based on its adequacy, shaped by the acceptable values of the goodness-of-fit indexes (the extent of the fitness of the theoretical model with the research data) (Tabachnick \& Fidell, 2001). Then, the structural model was appreciated. 


\section{Findings / Results}

\section{Initial analyses}

In the proposed model, academic confidence and psychological capital were exogenous latent variables, and academic coping strategies were endogenous mediator latent variables. Academic success was endogenous latent variable. Before examining the structural model, the indicators of academic confidence, psychological and academic coping strategies were formed. For academic success, an indicator formation was not made due to assessing that variable through only one value (GPA score).

In order to form the indicators of academic confidence (Academic Study Planning, Verbalizing, Project/Assignment Organization), item parceling approach, one of the partially disaggregated model techniques, was applied. In the partially disaggregated model, parcels are formed via summing up multiple items. Item parceling refers to the procedure of clustering the items through different methods such as factor analysis, correlation etc. and calculating the sums of the items in each cluster to utilize the parcels as the indicators of latent variables (Bandalos \& Finney, 2001). The techniques used in item parceling changes depending on the nature of the model formed by the researcher. For example, when a concept is assessed via multifactor scale and the total score is obtained, a hierarchical model is represented. In such a model, parcels are formed through aggregating the items in each factor of the concept (Coffman \& MacCallum, 2005). In our study, the latent variable - academic confidence - made up a hierarchical model as it was the second-level factor while its subfactors -Academic Study Planning, Verbalizing and Project/Assignment Organization- were the first-level factors. The parcels were formed through summing up the items in each sub-factor of academic confidence and considered as its indicators. However, the other latent variable - academic coping strategieswas examined through a scale in which a total score cannot be obtained. Therefore, its indicators - Approach, Avoidance and Social Support - were studied with a different item parceling method called correlation algorithm. In this method, the bivariate correlations of all items are calculated. The first parcel includes the pair of the items with the highest correlation, the second parcel involves the pair of the items with the second highest correlation, and so on until all parcels are formed (Matsunaga, 2008). In this respect, for Approach sub-factor, four parcels; for Avoidance sub-factor, three parcels and for Social Support sub-factor, two parcels were formed.

In identifying the indicators of psychological capital, total aggregation model was used. This model is a procedure used when a concept is assessed via more than one scale. It includes summing up the items in each subscale and utilizes the total scores as the indicators of the latent variable (Bagozzi \& Edwards, 1998). In our study, to test psychological capital, the scales assessing its components - hope, academic self-efficacy, resilience and optimism - were utilized and the total scores for each scale were considered as the indicators of psychological capital.

After the formation of indicators for each latent variable, two-step approach developed by Anderson and Gerbing (1988) was applied in order to test the hypothesized academic success model. The model fit indexes of the measurement model were tested based on the acceptable values specified by Tabachnick and Fidell (2007), and Schumacker and Lomax (2010). The results show that the fit indexes are in acceptable levels $\left(\chi^{2}(104)=190.65, p<.001\right.$; RMSEA = .05; SRMR = .04; NNFI = .96; CFI = .95). After the confirmation of the measurement model, each path in the hypothesized model was tested. All direct, indirect and total effects in the model were analyzed.

1) The findings related to the direct effects of the model:

Path A (Academic Confidence $\rightarrow$ Academic Success) - Model I:

In order to test Hypothesis-1, the model including academic confidence and academic success was examined and shown in Figure 2.

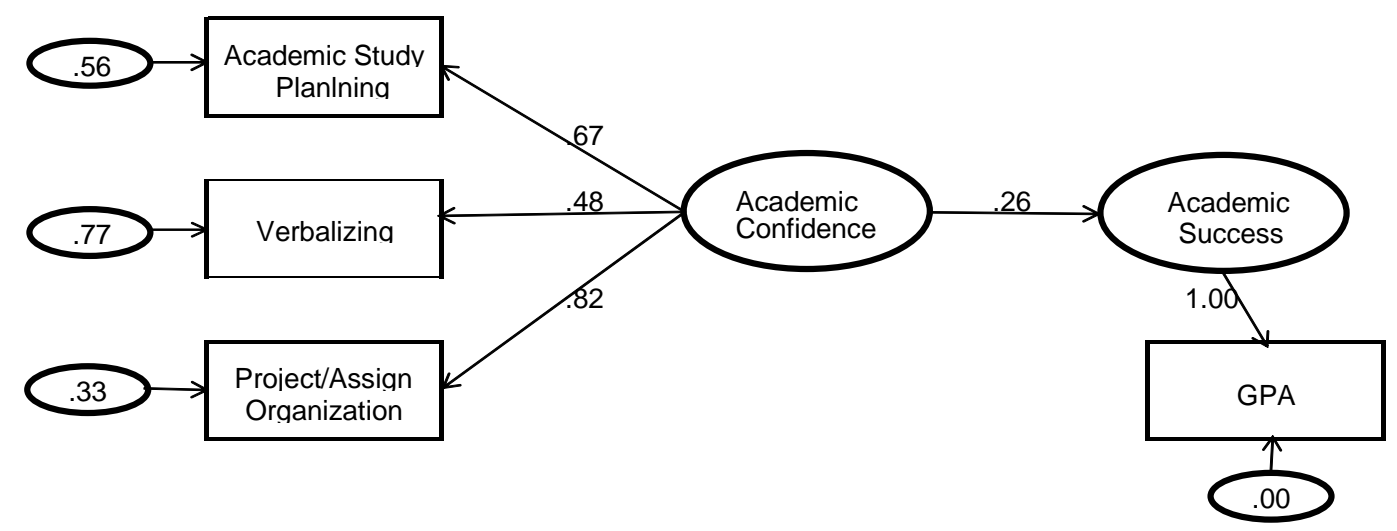

Chi-Square $=8.45, \mathrm{df}=4, \mathrm{P}$-value $=.07650, \mathrm{RMSEA}=.053$

Figure 2. Standardized regression coefficients for the direct relationship between academic confidence and academic success (Model I) 
As it is indicated in Figure 2, in the structural model including academic confidence and academic success, the relation between these variables was found as statistically significant $(t=4.55, p<.01)$. Model fit indexes were examined and they were in good levels $\left(\chi^{2}{ }_{4}=8.45, p>.05\right.$; RMSEA $=.05$; SRMR $=.03$; NNFI = .98; CFI $\left.=.98\right)$. This result showed that students' academic confidence scores significantly predicted their scores of academic success in a positive direction $\left(\beta_{\text {Acacon }} \rightarrow\right.$ Acasuc $\left.=.26\right)$.

Path B (Psychological Capital $\rightarrow$ Academic Success) - Model II:

In order to test Hypothesis-2, the model including psychological capital and academic success was examined and shown in Figure 3.

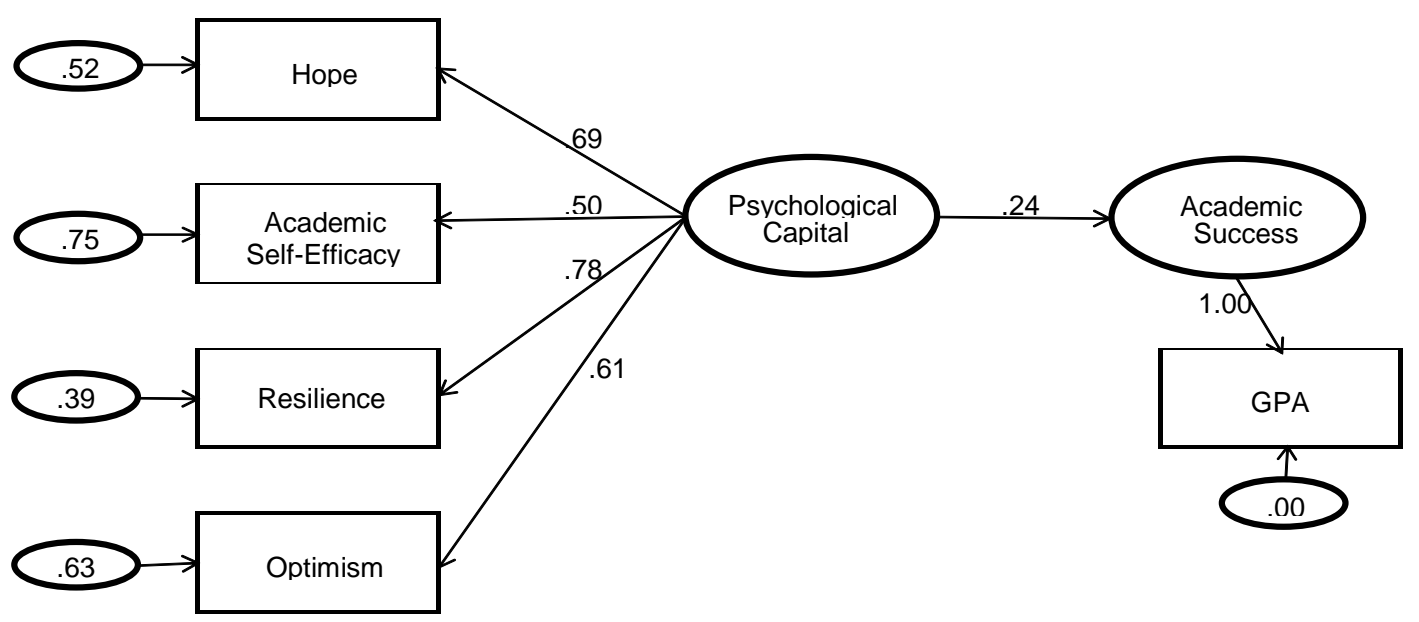

Chi-Square $=19.29, \mathrm{df}=8, \mathrm{P}$-value $=.01338, \mathrm{RMSEA}=.059$

Figure 3. Standardized regression coefficients for the direct relationship between psychological capital and academic success (Model II)

As it is shown in Figure 3, in the structural model including psychological capital and academic success, the relation between these variables was found as statistically significant $(t=4.27, p<.01)$. Model fit indexes were in good and acceptable levels $\left(\chi^{2}{ }_{(8)}=19.29, p<.05\right.$; RMSEA $=.06$; SRMR $=.04$; NNFI = .97; CFI $\left.=.98\right)$. This finding indicated that students' psychological capital scores significantly predicted their scores of academic success in a positive direction $\left(\beta_{\text {Psycap } \rightarrow \text { Acasuc }}=.24\right)$.

Path A \& Path B (Academic Confidence \& Psychological Capital $\rightarrow$ Academic Success) - Model III:

In order to test Hypothesis-3, the model including academic confidence, psychological capital and academic success was examined and shown in Figure 4. 


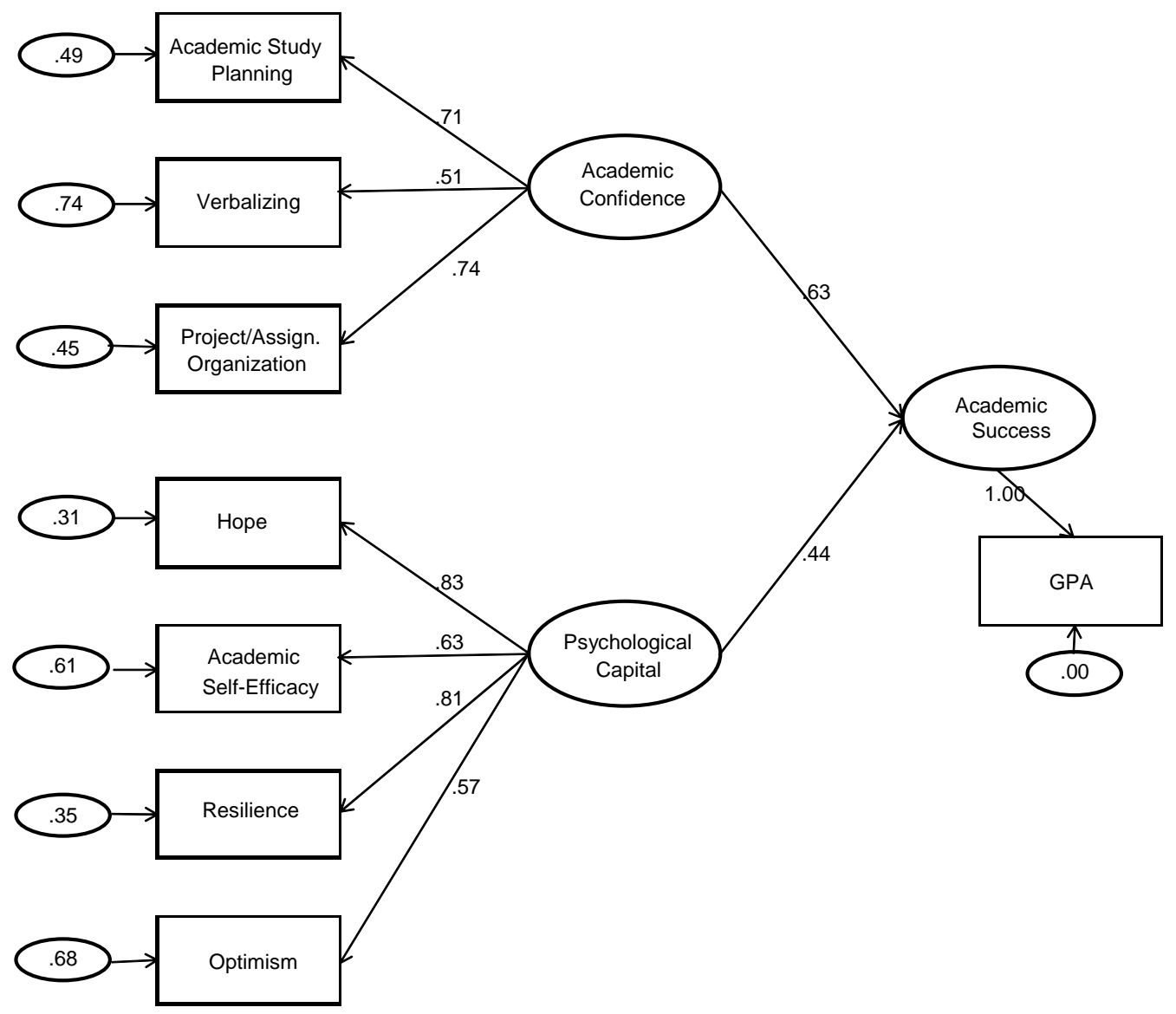

Chi-Square $=68.26, \mathrm{df}=23, \mathrm{P}$-value $=.00000, \mathrm{RMSEA}=.070$

Figure 4. Standardized regression coefficients for the direct relationships between academic confidence, psychological capital and academic success (Model III)

As it is indicated in Figure 4, in the structural model including academic confidence, psychological capital and academic success, the relation between academic confidence and academic success $(t=4.50, p<.01)$, and the relation between psychological capital and academic success $(t=3.35, p<.01)$ were statistically significant. Model fit indexes were in acceptable levels $\left(\chi^{2}(23)=68.26, p<.001 ;\right.$ RMSEA $=.07$; SRMR $=.05$; NNFI $=.96$; CFI $\left.=.97\right)$. This result manifested that students' academic confidence and psychological capital scores significantly predicted their scores of academic success in a positive direction (respectively; $\beta_{\text {Acacon }} \rightarrow$ Acasuc $=.63, \beta_{\text {Psycap }_{\rightarrow} \text { Acasuc }}=.44$ ).

2) The findings related to the indirect effects of the model Path C \& D \& E (Academic Confidence \& Psychological Capital $\rightarrow$ Academic Coping $\rightarrow$ Academic Success) - Model IV:

In order to test Hypothesis-4, the model including the indirect effects of academic confidence and psychological capital on academic success was examined and shown in Figure 5. 


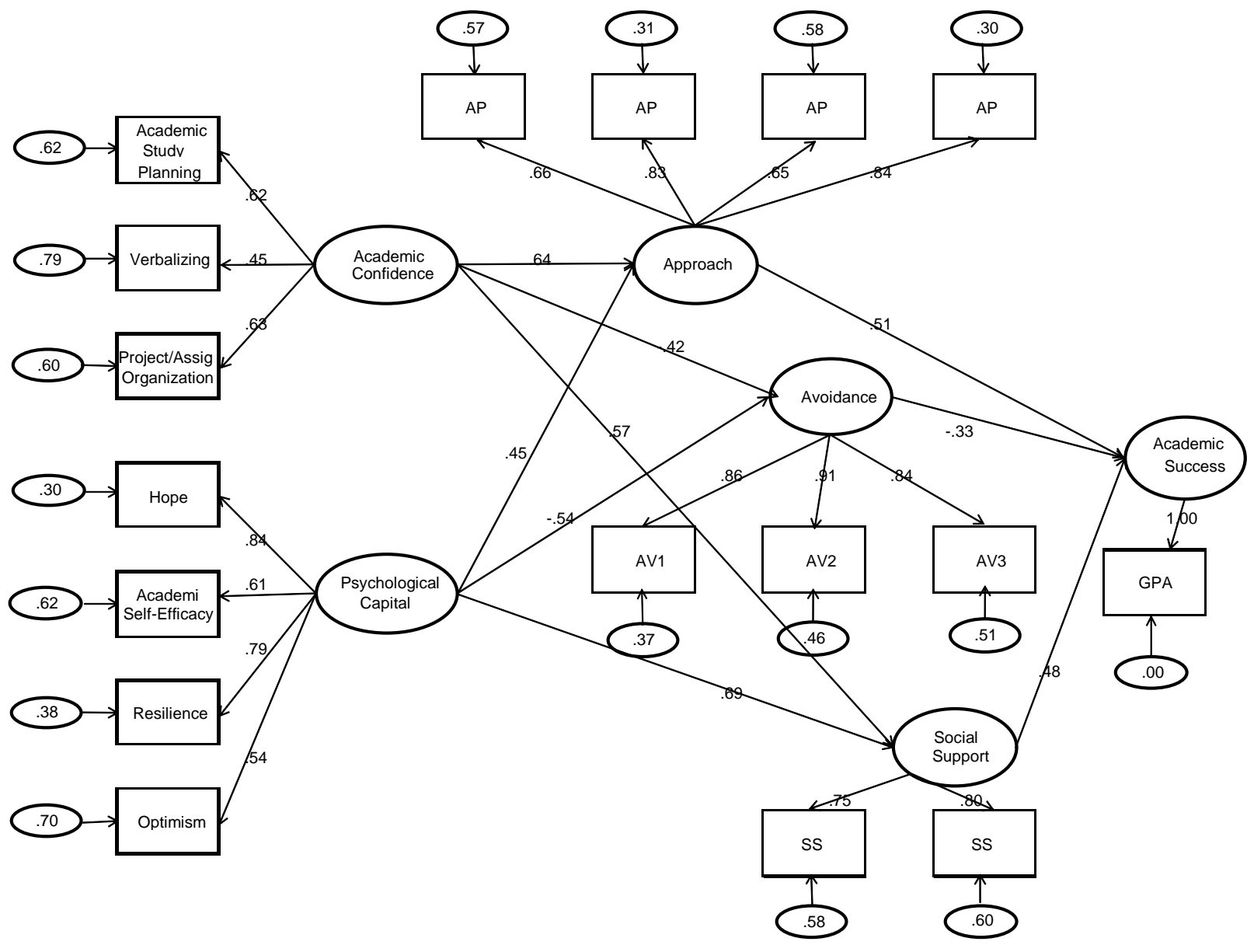

Chi-Square $=275.13, \mathrm{df}=121, \mathrm{P}$-value $=.00000, \mathrm{RMSEA}=.057$

Figure 5. Standardized regression coefficients for the indirect relationships between academic confidence, psychological capital, academic coping strategies and academic success (Model IV).

As it is shown in Figure 5, in the structural model including academic confidence, psychological capital, academic coping strategies and academic success, the relations between academic confidence and approach $(t=4.72, p<.01)$, and avoidance $(t=-3.17, p<.01)$, and social support $(t=4.40, p<.01)$ were statistically significant. Besides, the relations between psychological capital and approach $(t=3.25, p<.01)$, and avoidance $(t=-3.38, p<.01)$, and social support $(t=4.81$, $p<.01)$ were statistically pivotal. In addition, the relations between academic success and approach $(t=4.14, p<.05)$, and avoidance $(t=-3.06, p<.01)$, and social support $(t=3.59, p<.01)$ were statistically important.

When the model fit indexes were examined, the values were in acceptable levels $\left(\chi^{2}{ }_{(121)}=275.13, p<.001\right.$; RMSEA $=.06$; SRMR $=.05$; NNFI $=.98 ; \mathrm{CFI}=.98$ ). This result indicated that students' academic confidence and psychological capital

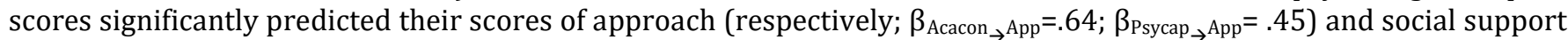
(respectively; $\beta_{\text {Acacon }_{\rightarrow} \text { Socsup }}=.57 ; \beta_{\text {ssycap }_{\rightarrow} \text { Socsup }}=.69$ ) in a positive direction unlike their scores of avoidance (respectively; $\left.\beta_{\text {Acacon }} \rightarrow{ }_{\text {Avo }}=-.42 ; \beta_{\text {Psycap }_{\rightarrow} \text { Avo }}=-.54\right)$. Moreover, it also showed that students' approach and social support scores significantly predicted their scores of academic success in a positive direction (respectively; $\beta_{\text {App } \rightarrow \text { Acasuc }}=.51$; $\beta_{\text {socsup }_{\rightarrow} \text { Acasuc }}=.48$ ) while their avoidance scores significantly predicted their scores of academic success in a negative

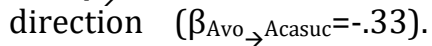

3) The findings related to the total effects of the model

Path $A \& B$ and Path $C \& D \& E$ \{(Academic Confidence and Psychological Capital $\rightarrow$ Academic Success) and (Academic Confidence and Psychological Capital $\rightarrow$ Academic Coping $\rightarrow$ Academic Success) $\}$ - Model V:

In order to test Hypothesis-5, the model including the total effects on academic success was examined and shown in Figure 6. 


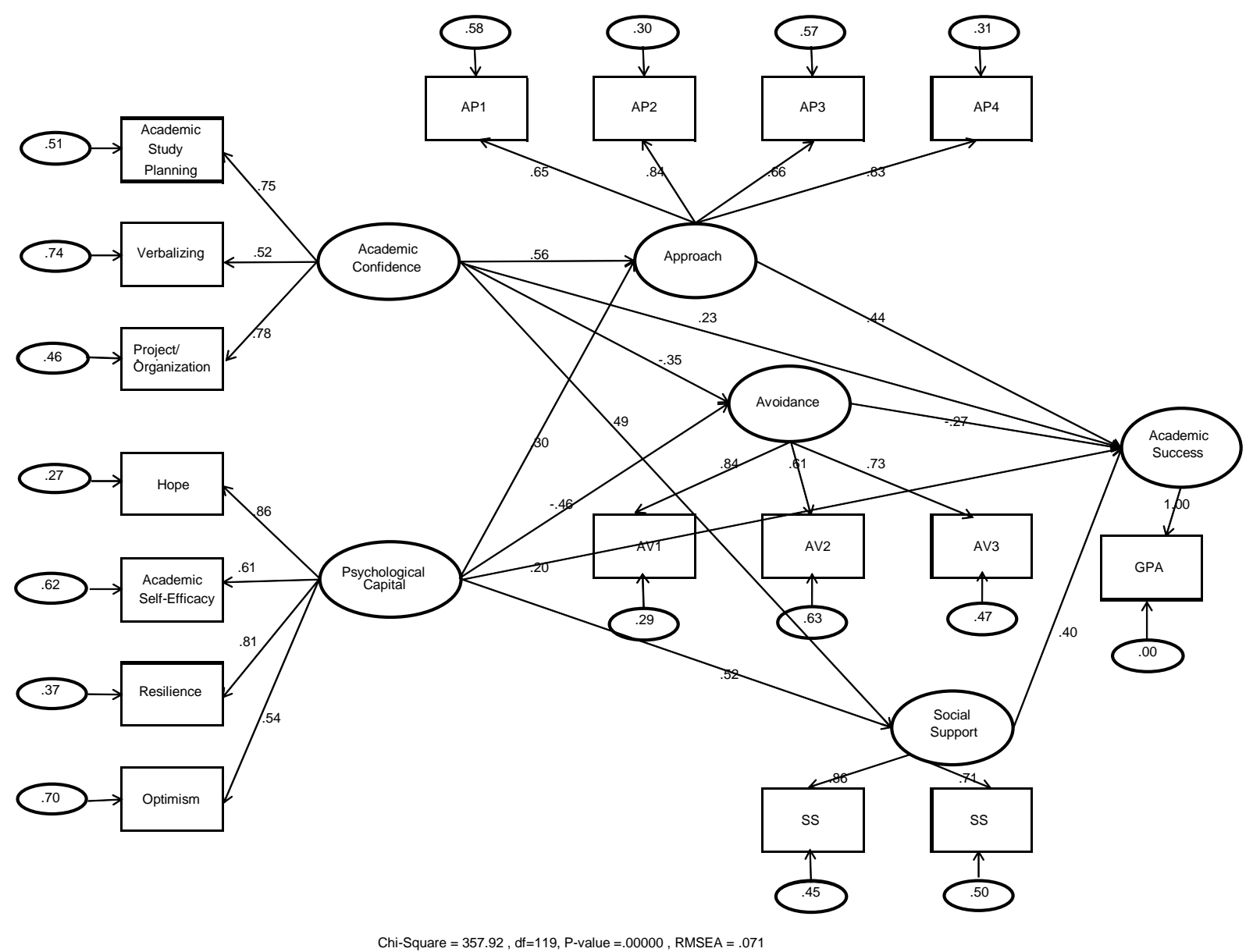

Figure 6. Standardized regression coefficients for the direct and indirect relationships between academic confidence, psychological capital, academic coping strategies and academic success (Model V).

As it is indicated in Figure 6, in the structural model including direct and indirect relations between academic confidence, psychological capital, academic coping and academic success, the relations between academic confidence and approach $(t=3.68, p<.01)$, and avoidance $(t=-2.63, p<.01)$, and social support $(t=3.01, p<.01)$, and academic success $(t=2.41, \mathrm{p}<.05)$ were statistically significant. In addition, the relations between psychological capital and approach $(t=2.54, p<.05)$, and avoidance $(t=-2.92, p<.01)$, and social support $(t=3.57, p<.01)$, and academic success $(t=2.36, \mathrm{p}<.05)$ were statistically pivotal. Moreover, the relations between academic success and approach $(t=2.85, p<.01)$, and avoidance $(t=-2.45, p<.05)$, and social support $(t=2.71, p<.01)$ were statistically important.

Furthermore, model fit indexes were in acceptable levels $\left(\chi^{2}(121)=357.92, p<.001 ; \mathrm{RMSEA}=.07 ; \mathrm{SRMR}=.07\right.$; NNFI = .95; CFI $=.95)$. This result indicated that students' academic confidence and psychological capital scores significantly predicted their scores of approach (respectively, $\beta_{\text {Acacon }}{ }_{\rightarrow} \mathrm{App}=.56 ; \beta_{\text {Psycap }_{\rightarrow} \mathrm{App}}=.30$ ) and social support (respectively, $\left.\beta_{\text {Acacon }}{ }_{\text {Socsup }}=.49 ; \beta_{\text {Psycap }_{\rightarrow} \text { Socsup }}=.52\right)$ in a positive direction unlike their scores of avoidance (respectively, $\beta_{\text {Acaconv }} \rightarrow{ }_{\text {Avo }}=-$ $\left..35 ; \beta_{\text {Psycap }_{\rightarrow} \text { Avo }}=-.46\right)$. In addition, students' approach $\left(\beta_{\text {App }_{\rightarrow} \text { Acasuc }}=.44\right)$ and social support $\left(\beta_{\text {Socsup }_{\rightarrow} \text { Acasuc }}=.40\right)$ scores significantly predicted their scores of academic success in a positive direction while their avoidance scores significantly predicted their scores of academic success in a negative direction ( $\beta_{\text {Avo } \rightarrow} \rightarrow_{\text {Acasuc }}=-.27$ ). Besides, students' academic confidence and psychological capital scores significantly predicted their scores of academic success in a positive direction (respectively; $\beta_{\text {Acacon }} \rightarrow_{\text {Acasuc=. }} 23 ; \beta_{\text {Psycap }_{\rightarrow} \text { Acasuc=.20) }}$

When the path coefficients in the Model V were analyzed, they were lower than the ones in the Model IV. Moreover, the direct path coefficients in Model I and Model II were higher than Model V. This finding showed that academic coping strategies were partial mediator variables between academic confidence, psychological capital and academic success.

\section{Discussion and Conclusion}

In order to examine the proposed model of academic success, the method suggested by Baron and Kenny (1986) was utilized. Especially, the mediator role of academic coping strategies was tested through the steps offered by these scholars, which involved the analyses of the direct, indirect and total paths in the models. 
When examining the direct paths in the study in detail, students who had high levels of academic confidence had high GPA scores. This result is consistent with the theoretical framework of academic confidence developed by Sander and Sanders (2006), and similar to the findings of the previous studies conducted by Palanivelu and Govindarajan (2012), Nicholson et al. (2013), and Sander, Putwain and de la Fuente (2013). In the study of Palanivelu and Govindarajan (2012), high school students having high degrees of academic confidence had high academic performance without any gender and place of residence differences. In Nicholson et al. (2013)'s study, undergraduates having high degrees of academic confidence had high GPA scores. Even the ones having unrealistic expectations about their courses had high GPA scores as they had high levels of academic confidence. In Sander et al. (2013)'s study, each dimension of academic confidence had a positive relation with academic success. The findings of the path analyses showed that Verbalizing and Attendance dimensions of academic confidence had a direct positive relation with academic success while Studying dimension had an indirect positive relation with academic success via learning approach strategy. Undergraduates having high Studying scores used more deep learning approach, leading them to have high GPA scores.

Sander and Sanders (2006) claim that this is because academic confidence has similar resources with self-efficacy involving 'enactive attainments, verbal persuasion, vicarious experience, and physiological state' claimed by Bandura (1982, p.126-127). Enactive attainments are the major reasons facilitating one's belief about himself in which he feels success through his accomplishments. Verbal persuasion also causes one to think that other people have a belief about him or her in terms of his or her potential success by stating "You can do it!". Physiological state enables the one to understand whether he can deal with the academic struggles with his bodily responses or not. Yet, academic confidence is a broader term than academic self-efficacy, as it indicates one's general beliefs about his study behaviors necessary for his academic survival in higher education (Bong \& Skaalvik, 2003; Sander \& Sanders, 2006).

Moreover, students having high levels of psychological capital had high GPA scores in the study. This result is consistent with the theoretical perspective of Luthans, Luthans and Jensen (2012) and similar to the findings of the past studies by Luthans et al. (2012) and Jafri (2013). In both of the studies, undergraduates having high psychological capital scores had high GPA scores. To Luthans et al. (2012), each component of psychological capital (self-efficacy, optimism, hope and resilience) has a shaping impact on students' academic performance. Self-efficacy, one' beliefs about his capacity or potentiality (Bandura, 1977, 1982, 1993), determines whether he completes a task effectively or not. Academic selfefficacy, one's beliefs about his academic skills contributing to a successful performance in a specific field (Bandura, 1977; Schunk, 1991), also has a predictive role on his level of attainments in educational settings (Chemers et al., 2001; Gore, 2006; Khan, 2013). Optimism, one's positive ideas about his future life (Scheier \& Carver, 1992, 2009), leads the one to have successful results in his educational life (Ruthig et al., 2004; Singh \& Jha, 2013). Hope, one's beliefs about whether he can find necessary solution pathways to attain specific goals and apply these pathways efficiently (Snyder et. al., 1991), has a facilitative role on obtaining accomplishments (Snyder et al., 2002; Day et al., 2010; Feldman \& Kubota, 2015). Resilience, one's positive adjustment to challenging settings and endurance to every stress-inducing event effectively (Masten \& Reed, 2002; Masten, 2007) causes the one to deal with academic problems adequately (Beauvais, Stewart, DeNisco, \& Beauvais, 2014; Allan, McKenna, \& Dominey, 2014). Therefore, each element in psychological capital has a positive relation with academic success, which in turn, makes that concept assist the progress of one's GPA scores (Luthans et al., 2012).

When analyzing the indirect paths in the study painstakingly, students having high levels of academic confidence and psychological capital had high levels of approach and social support, and low levels of avoidance academic coping strategies, which in turn, led to high GPA scores. The results of academic confidence are consistent with the theoretical ideas of Suls and Fletcher (1985), and Curlette et al. (1993), and similar to the findings of the study by Nounopolous, Ashby and Gilman (2006). In the study of Nounopolous et al. (2006), the students, who created their own academic criteria, used them in their motivation and had a small gap between their criteria and their performance. They had high levels of academic confidence which made up their academic coping resources, and high levels of GPA than the ones who had a big gap between them. The findings of psychological capital are also congruent with the theoretical ideas of Avey, Luthans and Jensen (2009), and similar to the findings of Qingquan and Zongkui (2009), Khan, Siraj and Li (2011), Li and Xiangpei (2011). To Avey et. al. (2009), all elements in psychological capital constitute the resources of one's coping strategies. In the literature, the findings related to the fact that there is a meaningful relation between selfefficacy (Khan, 2013), optimism (Fontaine et al., 2004; Hatchett \& Park, 2004; Nes \& Segerstrom, 2006), hope (Onwugbuzie \& Snyder, 2000), resilience (Steinhardt \& Dolbier, 2008; Gonzales-Torres \& Artuch-Garde, 2014) and coping strategies support the idea of Avey et al. (2009). In the study of Qingquan and Zongkui (2009), it was found that undergraduates having high degrees of psychological capital used more positive coping strategies, and they were mentally healthier than the ones having low degrees of psychological capital. In the research of Khan et al. (2011), undergraduates having high psychological capital scores strived more for solving their academic challenges and used more problem-focused coping strategy than the ones having low psychological capital scores. In the study of Li and Xiangpei (2011), female graduates having high psychological capital scores used more approach coping strategies than the other ones.

Besides, the predictive role of academic coping strategies on academic success is consistent with the findings of Struthers, Perry and Menec (2000), Hsieh, Sullivan, Sass and Guerra (2012), Kuncharin and Mohamad (2014). In the 
study of Struthers et al. (2000), the mediator roles of academic coping strategies and motivation between academic stress and academic performance were tested. They found that undergraduates having low degrees of academic stress used more problem-focused coping strategy and had high motivation scores, resulting in high academic performance unlike the ones having high academic stress. In the research of Hsieh et al. (2012), the impacts of self-control, selfefficacy, goal orientation, academic coping strategies and self-regulation on the relation between test anxiety and the scores at the end of the semester were examined. They found that undergraduates having mastery-goal orientation used more approach academic coping strategies and they were more successful than the other ones. The students having low self-efficacy used more avoidance academic coping strategies and had low academic performance. The students having high self-control and self-regulation scores were more successful than the other ones. In the study of Kuncharin and Mohamad (2014), undergraduates having high scores on social support academic coping strategies were more successful than the ones having high scores on avoidance academic coping strategies.

When examining the total paths in the study profoundly, students' scores of academic confidence and psychological capital partially shaped their scores of academic success via their scores of academic coping strategies. This result is congruent with the theoretical ideas of Sander and Sanders (2006), Curlette et al. (1993), Suls and Fletcher (1985), Luthans et al. (2012) and Avey et al. (2009) and Sullivan (2010). Academic confidence is considered as an important determinant of one's academic coping strategies (Curlette et al., 1993; Suls \& Fletcher, 1985) and academic success (Sander \& Sanders, 2006). Students who believe they can form their own academic pathway through their study behaviors are more likely to adopt approach and social support coping strategies, and have high levels of GPA. Besides, psychological capital is another variable shaping one's academic life. Especially, students who think that they can find alternative solutions when they have academic problems, who believe that they can attain accomplishments in a specific field with their abilities and skills, who have the idea that they can stand against academic challenges and can survive in such an environment, and who contemplate that there is a possibility of a good future are more likely to embrace approach and social support coping strategies (Avey et al., 2009) and have high degrees of academic success (Luthans et al., 2012). As Sullivan (2010) states, academic coping strategies are pivotal elements of one's academic achievements. For him, students who have approach and social support coping strategies are more likely to deal with academic stress better and become more successful than the ones who have avoidance coping strategies.

To sum up, in higher education, undergraduates' psychological resources are critical components shaping their academic performances. Helping undergraduates develop an awareness of their academic skills, psychological strengths and coping strategies is an effective way of organizing their academic success. Based on this awareness, they can have the feeling of "I have a control over my world of success" and they can increase the chances of proceeding in their academic life. Group guidance and counseling programs having the aim of helping undergraduates develop their levels of academic confidence, psychological capital and academic coping strategies can be very effective in eliminating their academic problems and increasing their academic performance. For future researches, this model can be analyzed in a longitudinal design as undergraduates start their academic journey in their Prep School. The model can also be examined with different study groups like high school students via using different measurement tools. In addition, the model can be tested whether it will produce different results in terms of undergraduates' personality traits, family relations (divorced, separate, etc.), socio-economic states and so on.

\section{References}

Abouserie, R. (1994). Sources and levels of stress in relation to locus of control and self esteem in university students. Educational Psychology: An International Journal of Experimental Educational Psychology, 14(3), 323-330.

Adebayo, B. (2008). Cognitive and non-cognitive factors: Affecting the academic performance and retention of conditionally admitted freshmen. Journal of College Admission, 200, $15-21$.

Akin, A. \& Cetin, B. (2007). Achievement Goal Orientations Scale: The study of validity and reliability. Eurasian Journal of Educational Research, 7(26), 1-12.

Akman, Y. \& Korkut, F. (1993). Umut Olcegi uzerine bir calisma. Hacettepe Universitesi Egitim Fakultesi Dergisi, 9, 193202.

Allan, J. F., McKenna, J. \& Dominey, S. (2014). Degrees of resilience: Profiling psychological resilience and prospective academic achievement in university inductees. British Journal of Guidance and Counseling, 42(1), 9-25.

Anderson, J. C. \& Gerbing, D. W. (1988). Structural equation modeling in practice: A review and recommended two-step approach. Psychological Bulletin, 103(3), 411-423.

Avey, J. B., Luthans, F. \& Jensen, S. M. (2009). Psychological capital: A positive resource for combating employee stress and turnover. Human Resource Management, 48(5), 677-693.

Aydin, G. \& Tezer, E. (1991). Iyimserlik, saglik sorunlari ve akademik basari iliskisi. Psikoloji Dergisi, 7(26), 2-9.

Bagozzi, R. P. \& Edwards, J. R. (1998). A general approach for representing constructs in organizational research. Organizational Research Methods, 1(1), 45-87. 
Bandalos, D. L. \& Finney, S. J. (2001). Item parceling issues in structural equation modeling. In G. A. Marcoulides \& R. E. Schumacker (Eds.), Advanced Structural Equation Modeling: New Developments and Techniques (pp. 269-296). NJ: Lawrence Erlbaum Associates.

Bandura, A. (1977). Self-efficacy: Toward theory of behavioral change. Psychological Review, 84(2), 191-215.

Bandura, A. (1982). Self-efficacy mechanism in human agency. American Psychologist, 37(2), 122-147.

Bandura, A. (1993). Perceived self-efficacy in cognitive development and functioning. Educational Psychologist, 28(2), 117-148.

Bandura, A. (1997). Self Efficacy: The Exercise of Control. NY: W. H. Freeman.

Beauvais, A. M., Stewart, J. G., DeNisco, S. \& Beauvais, J. E. (2014). Factors related to academic success among nursing students: A descriptive correlational research study. Nurse Education Today, 34(6), 918-923.

Bong, M. \& Skaalvik, E. M. (2003). Academic self-concept and self-efficacy: How different are they really? Educational Psychology Review, 15(1), 1-40.

Bartlett, J.E, Kotrlik, I.J.W. and Higgins, C.C. (2001). Organizational research: Determining the appropriate sample size in survey research. Information Technology, Learning and Performance Journal, 19(1) 43-50.

Baron, R. M. \& Kenny, D. A. (1986). The moderator-mediator variable distinction in social psychological research: Conceptual, strategic, and statistical considerations. Journal of Personality and Social Psychology, 51(6), 1173-1182.

Brown, S. D., Lent, R. W. \& Larkin, K. C. (1989). Self efficacy as a moderator of scholastic aptitude-academic performance relationships. Journal of Vocational Behavior, 35, 64-75.

Carver, C. S. \& Scheier, M. F. (2002). Optimisim. In C.R. Synder \& S.J. Lopez (Eds.), Handbook of Positive Psychology (pp.231-243), USA: Oxford Unversity Press.

Carveth, J. A. \& Geese, T. (1996). Survival strategies for nurse-midwifery students. Journal of Nurse-Midwifery, 41(1), 5054.

Chemers, M. M., Hu, L. T. \& Garcia, B. F. (2001). Academic self-efficacy and first-year college student performance and adjustment. Journal of Educational Psychology, 93(1), 55-64.

Coffman, D. L. \& MacCallum, R. C. (2005). Using parcels to convert path analysis models into latent variable models. Multivariate Behavioral Research, 40, 253-259.

Cohen, L., Manion, L. \& Morrison, K. (2007). Research Methods in Education (6th ed.). NY: Taylor \& Francis.

Curlette, W. L., Matheny, K. B., Aycock, D. W., Pugh, J. L., Taylor, H. F. \& Canella, K. S. (1993). The Coping Resources Inventory Scales for Educational Enhancement (CRISEE). Fayetteville, GA: Health Prisms, Inc.

Day, L., Hanson, K., Maltby, J., Proctor, C. \& Wood, A. (2010). Hope uniquely predicts objective academic achievement above intelligence, personality, and previous academic achievement. Journal of Research in Personality, 44, 550-553.

DeBerard, M. S., Spielmans, G. I. \& Julka, D. L. (2004). Predictors of academic achievement and retention among college freshmen: A longitudinal study. College Student Journal, 38(1), 66-80.

Demirel, O. (2015). Ogretim Ilke ve Yontemleri: Ogretme Sanati. (21.Baski). Ankara: Pegem Akademi.

Ensign, J. \& Woods, A. M. (2014). Strategies for increasing academic achievement in higher education. Journal of Physical Education, Recreation and Dance, 85(6), 17-22.

Esen, E. (2010). Academic achievement of Turkish and American students. Human Architecture: Journal of the Sociology of Self-Knowledge, 8(1), 125-140.

Feldman, D. B. \& Kubota, M. (2015). Hope, self-efficacy, optimism, and academic achievement: Distinguishing constructs and levels of specificity in predicting college grade-point average. Learning and Individual Differences, 37, $210-216$.

Fenollar, P., Roman, S. \& Cuestas, P. J. (2007). University students' academic performance: An integrative conceptual framework and empirical analysis. British Journal of Educational Psychology, 77, 873-891.

Fisek, G. (1982). Psychopathology and the Turkish family: A family systems theory analysis. In C. Kagitcibasi (Ed.), Sex Roles, Family, and Community in Turkey (pp. 295-321). Bloomington: Indiana University Press.

Fontaine, K. R., Manstead, A. S. R. \& Wagner, H. (2004). Optimism, perceived control over stress, and coping. European Journal of Personality, 7, 267-281.

Fraenkel, J. R. \& Wallen, N. E. (2006). How to Design and Evaluate Research in Education. (6th ed.). NY: McGraw-Hill. 
Gonzales-Torres, M. C. \& Artuch-Garde, R. (2014). Resilience and coping strategy profiles at university: Contextual and demographic variables. Electronic Journal of Research in Educational Psychology, 12(3), 621-648.

Gore, P. A. (2006). Academic self-efficacy as a predictor of college outcomes: Two incremental validity studies. Journal of Career Assessment, 14(1), 92-115.

Gunduz, B. (2014). Ogrenci kisilik hizmetleri ve rehberlik. In M. E. Deniz \& A. Erozkan (Ed.), Psikolojik Danisma ve Rehberlik (pp.3-30). Ankara: Maya Akademi.

Hatchett, G. T. \& Park, H. L. (2004). Relationships among optimism, coping styles, psychopathology, and counseling outcome. Personality and Individual Differences, 36, 1755-1769.

Hoyle, R. H. (1995). Structural Equation Modeling: Concepts, Issues, and Applications. USA: Sage Publications.

Hsieh, P. H., Sullivan, J. R., Sass, D. A. \& Guerra, N. S. (2012). Undergraduate engineering students' beliefs, coping strategies, and academic performance: An evaluation of theoretical models. The Journal of Experimental Education, 80(2), 196-218.

Huang, S. (2011). Predicting students' academic performance in college using a new non-cognitive measure: An instrument design and a structural equation exploration of some non-cognitive attributes and academic performance. Unpublished Doctorate Dissertation, The Ohio State University, Graduate School of Education, USA.

Jafri, H. (2013). A study of the relationship of psychological capital and students' performance. Business Perspectives and Research, 1(2), 9-16.

Kagitcibasi, C. (2005). Autonomy and relatedness in cultural context: Implications for self and family. Journal of CrossCultural Psychology, 36(4), 403-422.

Khan, A., Siraj, S. \& Li, L. P. (2011). Role of positive psychological strenghts and big five personality traits in coping mechanism of university students. International Proceedings of Economics Development and Research, 20, 210-215.

Khan, M. (2013). Academic self-efficacy, coping, and academic performance in college. International Journal of Undergraduate Research and Creative Activities, 5, 1-11.

Kirikkanat, B. \& Kali Soyer, M. (2015). The Academic Behavioral Confidence Scale: The Adaptation Study With Turkish Undergraduates. International Journal of Technical Research and Applications, 1(30), 11-20.

Kirikkanat, B. \& Kali Soyer, M. (2016). Adaptation of The Academic Coping Strategies Scale in Turkey: A Study With Undergraduates. International Journal of Teaching and Education, 4(1), 26-44.

Kline, R. B. (2005). Principles and Practice of Structural Equation Modeling. (2nd ed.). NY: The Guilford Press.

Kuncharin, L. \& Mohamad, A. R. B. (2014). Coping strategies on academic performance among undergraduate students in Thailand. The Standard International Journals (The SIJ) Transactions on Industrial, Financial and Business Management (IFBM), 2(3), 58-61.

Kuzgun, Y. (2013). Rehberlik ve Psikolojik Danisma (12.Baski). Ankara: Nobel Akademik Yayincilik.

Kwok, O., Hughes, J. N. \& Luo, W. (2007). Role of resilient personality on lower achieving first grade students' current and future achievement. Journal of School Psychology, 45(1), 61-82.

Lazarus, R. S. \& Folkman, S. (1984). Stress, Appraisal, and Coping. NY: Springer Publishing Company.

Li, L. I. \& Xiangpei, H. E. (2011). The researches on positive psychological capital and coping style of female university graduates in the course of seeking jobs. In J. K. Hung (Ed.), Proceedings of 2011 International Symposium - The Female Survival of Development (pp. 221-226). Australia: St. Plum Blossom Press.

Luthans, F., Youssef, C. M. \& Avolio, B. J. (2007). Psychological Capital. NY: Oxford University Press.

Luthans, B.C., Luthans, K.W. \& Jensen, S.M. (2012). The impact of business school students' psychological capital on academic performance. Journal of Education for Business, 87(5), 253-259.

Martin, A. J. \& Marsh, H. W. (2009). Academic resilience and academic buoyancy: Multidimensional and hierarchical conceptual framing of causes, correlates and cognate constructs. Oxford Review of Education, 35(3), 353-370.

Masten, A. S. \& Reed, M. G. J. (2002). Resilience in development. In C.R. Synder \& S.J. Lopez (Eds.), Handbook Positive Psychology (pp.74-88), USA: Oxford Unversity Press.

Masten, A. S. (2007). Resilience in developing systems: Progress and promise as the fourth wave rises. Development and Psychopathology, 19(3), 921-930.

Matsunaga, M. (2008). Item parceling in structural equation modeling: A primer. Communication Methods and Measures, $2(4), 260-293$. 
Messick, S. (1979). Potential uses of noncognitive measurement in education. Journal of Educational Psychology, 71(3), 281-292.

Multon, K. D., Brown, S. D. \& Lent, R. W. (1991). Relation of self-efficacy beliefs to academic outcomes: A meta-analytic investigation. Journal of Counseling Psychology, 38(1), 30-38.

Nes, L. S. \& Segerstrom, S. C. (2006). Dispositional optimism and coping: A meta-analytic review. Personality and Social Psychology Review, 10(3), 235-251.

Nicholson, L., Putwain, D., Connors, L. \& Hornby-Atkinson, P. (2013). The key to successful achievement as an undergraduate student: Confidence and realistic expectations?. Studies in Higher Education, 38(2), $285-295$.

Nounopoulos, A., Ashby, J. S. \& Gilman, R. (2006). Coping resources, perfectionism, and academic performance among adolescents. Psychology In The Schools, 43(5), 613-622.

Onwuegbuzie, A. J. \& Snyder, C. R. (2000). Relations between hope and graduate students' coping strategies for studying and examination-taking. Psychological Reports, 86, 803-806.

Ozguven, I. E. (2014). Psikolojik Testler. (12th ed.). Ankara: Nobel Yayinevi.

Palanivelu, G. \& Govindarajan, K. (2012). Relationship between the academic confidence and the academic achievement of the higher secondary students studying in Tanjore district. International Journal of Teacher Educational Research, 1(3), 1-7.

Putwain, D., Sander, P. \& Larkin, D. (2013). Academic self-efficacy in study-related skills and behaviors: Relations with learning-related emotions and academic success. British Journal of Educational Psychology, 83, 633-650.

Qingquan, P. \& Zongkui, Z. (2009). Psychological capital, coping style and psychological health: An empirical study from college students. 1st International Conference on Information Science and Engineering (ICISE): 26-28 December 2009 (pp. 3391-3394), Nanjing: IEEE.

Randsdell, S. (2001). Predicting college success: The importance of ability and non-cognitive variables. International Journal of Educational Research, 35, 357-364.

Rao, P. S. R. S. (2000). Sampling Methodologies with Applications. Florida: Chapman \& Hall / CRC.

Raykov, T. \& Marcoulides, G. A. (2006). A First Course in Structural Equation Modeling. (2nd ed.). NJ: Lawrence Erlbaum Associates.

Richardson, M., Abraham, C. \& Bond, R. (2012). Psychological correlates of university students' academic performance: A systematic review and meta-analysis. Psychological Bulletin, 138(2), 353-387.

Ross, S. E., Niebling, B. C. \& Heckert, T. M. (1999). Sources of stress among college students. College Student Journal, 33(2), 312-317.

Ruthig, J. C., Perry, R. P., Hall, N. C. \& Hladkyj, S. (2004). Optimism and attributional retraining: Longitudinal effects on academic achievement, test anxiety, and voluntary course withdrawal in college students. Journal of Applied Social Psychology, 34(4), 709-730.

Sander, P. \& Sanders, L. (2006). Understanding academic confidence. Psychology Teaching Review, 12(1), 29-42.

Sander, P., Putwain, D. \& de la Fuente, J. (2013). Using structural equation modelling to understand predictors of undergraduate students' academic performance. Theory and Method in Higher Education Research: International Perspectives on Higher Education Research, 9, 219-241.

Sanders, L. \& Sander, P. (2003). Academic behavioral confidence: A comparison of medical and psychology students. Electronic Journal of Resarch in Educational Psychology, 13(5), 633-650.

Schaefers, K. G., Epperson, D. L. \& Nauta, M. M. (1997). Women's career development: Can theoretically derived variables predict persistence in engineering majors? Journal of Counseling Psychology, 44, 173-183.

Scheier, M. F. \& Carver, C. S. (1985). Optimism, coping, and health: Assessment and implications of generalized outcome expectancies. Health Psychology, 4(3), 219-247.

Scheier, M. F. \& Carver, C. S. (1992). Effects of optimism on psychological and physical well-being: Theoretical overview and empirical update. Cognitive Therapy and Research, 16, 201-228.

Scheier, M. F. \& Carver, C. S. (2009). Optimism. In S. J. Lopez (Ed.), The Encyclopedia of Positive Psychology (pp.656-663). Oxford: Wiley-Blackwell.

Schumacker, R. E. \& Lomax, R. G. (2010). A Beginner's Guide to Structural Equation Modeling. (3rd ed.). NY: Routledge Taylor \& Francis Group. 
Schunk, D. H. (1991). Self-efficacy and academic motivation. Educational Psychologist, 26, 207-231.

Sing, I. \& Jha, A. (2013). Anxiety, optimism and academic achievement among students of private medical and engineering colleges: A comparative study. Journal of Educational and Developmental Psychology, 3(1), 222-233.

Siu, O. L., Bakker, A. B. \& Jiang, X. (2014). Psychological capital among university students: Relationships with study engagement and intrinsic motivation. Journal of Happiness Studies, 15(4), 979-994.

Skinner, E. A., Edge, K., Altman, J. \& Sherwood, H. (2003). Searching for the structure of coping: A review and critique of category systems for classifying ways of coping. Psychological Bulletin, 129(2), 216-269.

Snyder, C. R., Harris, C., Anderson, J. R., Holleran, S. A., Irving, L. M., Sigmon, S. T. et. al. (1991). The wills and the ways: Development and validation of an individual-differences measure of hope. Journal of Personality and Social Psychology, 60(4), 570-585.

Snyder, C. R. (2002). Hope theory: Rainbows in the mind. Psychological Inquiry, 13(4), 249-275.

Snyder, C. R., Shorey, H. S., Cheavens, J., Pulvers, K. M., Adams III, V. H. \& Wiklund, C. (2002). Hope and academic success in college. Journal of Educational Psychology, 94(4), 820-826.

Steinberg, L. (2002). Adolescence. (9th Ed.). USA: McGraw-Hill.

Steinhardt, M. \& Dolbier, C. (2008). Evaluation of a resilience intervention to enhance coping strategies and protective factors and decrease symptomatology. Journal of American College Health, 56(4), 445- 453.

Steptoe, A. \& Marmot, M. (2003). Burden of psychosocial adversity and vulnerability in middle age: Associations with biobehavioral risk factors and quality of life. Psychosomatic Medicine, 65(6), 1029-1037.

Struthers, C. W., Perry, R. P. \& Menec, V. H. (2000). An examination of the relationship among academic stress, coping, motiation and performance in college. Research in Higher Education, 41(5), 581-592.

Sullivan, J. R. (2010). Preliminary psychometric data for the Academic Coping Strategies Scale. Assessment for Effective Intervention, 35(2), 114-127.

Suls, J. \& Fletcher, B. (1985). The relative efficacy of avoidant and nonavoidant coping strategies: A meta-analysis. Health Psychology, 4(3), 249-288.

Tabachnick, B. G. \& Fidell, L. S. (2007). Using Multivariate Statistics. (5th ed.). USA: Pearson Education

Taylor, S. E. \& Stanton, A. L. (2007). Coping resources, coping processes, and mental health. The Annual Review of Clinical Psychology, 3, 377-401.

Terzi, S. (2006). Kendini Toparlama Gucu Olceginin uyarlanmasi: Gecerlik ve guvenirlik calismalari. Turk Psikolojik Danisma ve Rehberlik Dergisi, 3(26), 77-86.

Thien, L.M. \& Razak, N.A. (2013). Academic coping, friendship quality, and student engagement associated with student quality of school life: A partial least square analysis. Social Indicators Research, 112(3), 679-708.

Thomas, J. W. \& Rohwer, W. D. (1986). Academic studying: The role of learning strategies. Educational Psychologist, 21, 19-41.

The Council of Higher Education. (2017a). Unit statistics: Number of units by types. Retrieved from https://istatistik.yok.gov.tr/

The Council of Higher Education. (2017b). Higher education statistics: Number of vocational training school \& $\begin{array}{lllll}\text { undergraduate students fila } & \text { Retrieved }\end{array}$ https://istatistik.yok.gov.tr/yuksekogretimIstatistikleri/2017/2017_T12.pdf

The Council of Higher Education. (2017c). Higher education statistics: Summary table of number of graduates [Data file]. Retrieved from https://istatistik.yok.gov.tr/yuksekogretimIstatistikleri/2017/2017_M1.pdf

The Council of Higher Education. (2017d). Higher education statistics: Number of academic units by types [Data file]. Retrieved from https://istatistik.yok.gov.tr/yuksekogretimIstatistikleri/2017/2017_T107.pdf

Turkish Statistical Institute (2017). Labor force statistics: The rate of unemployment. Retrieved from http://www.tuik.gov.tr/HbGetirHTML.do?id=24634

Ting, S. M. R. (2003). A longitudinal study of non-cognitive variables in predicting academic success of first-generation college students. College and University, 78(4), 27-31.

Wagnild, G. M. \& Young, H. M. (1993). Development and psychometric evaluation of the Resilience Scale. Journal of Nursing Measurement, 1(2), 165-178. 
Yilmaz, M., Gurcay, D. \& Ekici, G. (2007). Akademik Oz-yeterlik Olceginin Turkce'ye uyarlanmasi. Hacettepe Universitesi Egitim Fakultesi Dergisi, 33, 253-259.

Yilmaz, M. B. \& Orhan, F. (2011). The validity and reliability study of the Turkish version of the Study Process Questionnaire. Education and Science, 36 (159), 70-83.

York, T. T. (2015). Defining and measuring academic success. Practical Assessment, Research and Evaluation, 20(5), 120. 